\title{
Causality Between GPD Growth and Non-performing Loans in Bangladesh: A Toda-Yamamoto Approach
}

\author{
Md. Ziaul Hasan \\ Centre for Higher Studies and Research, Bangladesh University of Professionals, Dhaka, Bangladesh
}

\section{Email address:}

md.ziaulhasan@ucb.com.bd

\section{To cite this article:}

Md. Ziaul Hasan. Causality Between GPD Growth and Non-performing Loans in Bangladesh: A Toda-Yamamoto Approach. International Journal of Finance and Banking Research. Vol. 5, No. 5, 2019, pp. 126-131. doi: 10.11648/j.ijfbr.20190505.12

Received: September 20, 2019; Accepted: October 15, 2019; Published: October 23, 2019

\begin{abstract}
Non-performing Loans (NPLs) are those loans of the banks' from which they are no longer able to receive interest or overdue principal payments. NPL can affect the balance sheet of banks by decreasing banks' profitability as bank cannot generate interest income from their NPLs. Banks' may have to face capital erosion due to higher level of NPL. Due to interconnectedness of banking sector with the overall financial system and the economy, there may have ripple effects throughout the financial system thereby adding to financial instability. The percentage of NPLs to total outstanding loans in Bangladesh was 9.3\% in 2017 . The aim of this paper is to investigate the causal relationship and the direction of causality between economic growth Gross Domestic Product Growth Rate (GDPGR) and the level of NPLs (NPLR) in Bangladesh using annual data covering the period from 2000 to 2017 within a vector autoregressive (VAR) framework using Toda-Yamamoto method. The main merit of the Toda-Yamamoto procedure is that it can be used irrespective of whether the time series in the system are integrated of different orders or non-cointegrated or both. The order of integration of the variables is initially determined using Augmented Dickey Fuller (ADF) unit root tests. The tests reveal that the maximum order of integration for the variables in the system is one. Applying Toda-Yamamoto approach of Granger causality test, an evidence of a unidirectional causality running from NPLR to GDPGR in Bangladesh is found. This research is expected to come out with good findings which will have implications for the policy makers, regulatory authorities and professionals.
\end{abstract}

Keywords: Non-performing Loans, Bangladesh, GDP Growth, Toda Yamamoto

\section{Introduction}

Banks play the foremost role in the developing economy like Bangladesh for mobilizing savings from the surplus economic unit and providing capital to the investors. Banks' performance has significant impacts on allocation of capital and economic growth. Thus, performance of banks is very much important not only for that specific bank, but also for the entire economy. Providing loans and advances to the customers is the banks' prime revenue generating activity. Generally, the loans and advances are the major portion of the banks' asset and their main source of income [1].

The term "NPL" is used interchangeably with "bad loans" as described by Basu [9]. Berger and De Young indicate NPLs as "problem loans" [11]. Fofack termed it as "impaired loans" [19]. In the banking industry of Bangladesh the term "Classified Loans" is also used to indicate NPL. Hou and Bloem mentioned in their studies that, globally acceptable definition of NPL is not yet formulated [13], [22]. Banking systems of different countries define loan classification system with different scopes and contents. Issa shows that there are variations in definition of NPL among the banking systems of different countries according to their laws and regulations [24]. Bloem show that, banks used both quantitative and qualitative criteria to classify the loans [13]. Usually, number of days is used as a quantitative criterion of loan classification and all the information about the future of the borrower and loans are used as qualitative criteria for classification of loans.

Non-performing Loans (NPLs) are those loans of the banks' from which they are no longer able to receive interest or overdue principal payments. So, NPLs decrease banks' profitability. Increase in NPL also decreases the loanable fund in the financial market. Banks' may have to face capital erosion due to higher level of NPLs. NPLs can affect the balance sheet of banks and 
due to interconnectedness of banking sector with the overall financial system and the economy, there may have ripple effects throughout the financial system thereby contributing to financial instability. Thus, exploring the affecting factors of NPLs is a matter of essential importance for the regulatory authorities, banks and governments concerned on financial stability. Determinants of NPL have been analyzed by many researchers and GDP growth rate is found influential on the level of NPL. GDP growth rate is a macroeconomic variable which are not in control of the banking institutions, may have significant causal impact on the non-performing loan.

\subsection{Impact of NPLs on Banking Growth}

A bank having a high level of NPLs has to incur carrying costs on non-income generating assets that affect not only the profitability but also the capital adequacy of a bank, and in consequence, the bank faces difficulties in augmenting capital resources. A study from IMF found that countries where the banks have high levels of NPLs credit growth remains slow. Firms those are more dependent on bank finance are likely to be affected more than other firms from the reduced lending capacity of banks. It was also mentioned from IMF that banks that have high levels of NPLs on their balance sheets, they also have a lower ability for lending to the real economy. This happens through 3 major channels:

Lower profitability: A high NPL level implies less net operating income for a bank and also reduce profits significantly due to the greater effort that required in order to manage and monitor the large stock of NPLs.

Higher capital requirements: An increased level of NPL increases the risk weights and as a result higher capital requirements will be needed.

Higher funding cost: Other Banks and investors have less willingness to lend or lend with higher rate of interest to the banks having higher level of NPLs [23].

\subsection{Impact of NPLs on Economy}

As per the ECB annual review high level of 'Non Performing Exposure's or NPEs (i.e. NPLs) create a severe macro prudential problem. First, a large stock of NPLs indicates that households and firms are excessively indebted and impaired, which may decrease consumption and investment, and consequently delay economic recovery. Second, scarce resources in the banking sector, capital, funding, as well as operational capacity, are absorbed by bad assets (NPLs) and cannot be reinvested in new viable investment projects. This, in turn, may elongate the period of subdued economic activity, further aggravating the NPL problem for the banking sector and the economy as a whole'.

\subsection{NPLs in Bangladesh}

In the context of Bangladesh, well-functioning of the banking sector and subsequent economic development has been significantly constrained by the continuing crisis of the accumulation of NPLs. To ensure transparency and quality of the banks' loan portfolios, determine the actual volume of quality assets and strengthen credit discipline, Bangladesh Bank, in 1989, adopted prudential norms under Financial Sector Reform Program (FSRP) for Loan Classification and Provisioning covering rules, the suspension of interest due, and the making of provisions against potential loan loss.

According to IMF, A loan is non-performing when payments of interest and principal are past due by 90 days or more, or at least 90 days of interest payments have been capitalized, refinanced or delayed by agreement, or payments are less than 90 days overdue, but there are other good reasons to doubt that payments will be made in full. By bank regulatory definition non-performing loans consist of:

$\mathrm{i}$ Loans that are past due by 90 days or more and still accruing interest, and

ii Loans which have been placed on nonaccrual (i.e., loans for which interest is no longer accrued and posted to the income statement).

Loan may also be non-performing if it is used in a different way than that for which it has been taken. As per Section 5 (cc) of Bank Company Act 1991, 'defaulting debtor' means any person or institution served with advance, loan granted in favour of him or an institution involving interest or any portion thereof, or any interest which has been overdue for six months in accordance with the definition of Bangladesh Bank. According to Bangladesh Bank "classified loan" is the term used for any loan that a bank examiner has deemed to be in danger of defaulting. The borrower does not necessarily need to miss payments order for a bank to label the account in this manner. The ratio of gross non-performing loan to total outstanding is called the NPL rate.

\subsection{Present Scenario}

In the banking industry of Bangladesh, the ratio of gross non-performing loan to total outstanding is $14.6 \%$ for the last eighteen years but A steady average NPL trend of $9.2 \%$ has been maintaining during the last five years and average GDP growth rate is 5.95 for the last eighteen years.

The overall trend of NPL and GDP growth rate rate in Bangladesh from the beginning of this century is shown in the following figure.

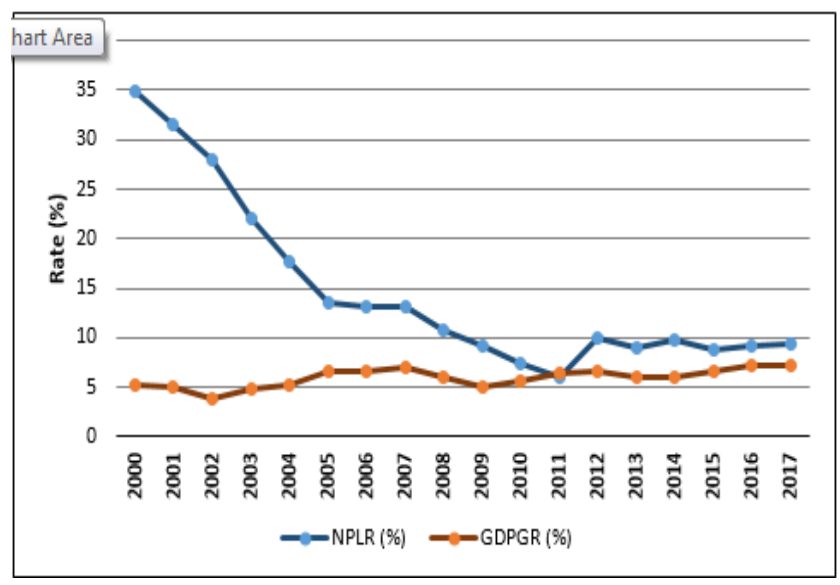

Source: Bangladesh Bank and World Bank Group

Figure 1. NPL Rate and GDP Growth Rate trend in Bangladesh. 


\section{Literature Review}

There are many studies conducted all over the world on the problem of NPL in the banking sector.

Makri et al. show strong correlations between various bank-specific and macroeconomic factors by using aggregate data for the period 2000-2008 on a panel of 14 countries [38]. Ekanayake et al. show that, macroeconomic variables like inflation and GDP growth rate have significant inverse relationship with NPLs [18].

Lis et al. econometrically identified various bank-specific and macroeconomic factors of NPL by using panel data of Spanish commercial banks for the period 1985-1997. They found that GDP growth rate has a negative effect on NPL [35]. Salas and Saurina found out the relationship between real growth in GDP and NPLs by studying Spanish banks' data [48].

Keeton and Morris studied on US commercial banks using simple linear regressions and found that large portion of loan losses recorded by the banks are associated to adverse local economic conditions [28]. Bercoff et al examined the fragility of the Argentinean Banking system over the 1993- 1996 periods; they argue that NPLs are affected by both bank specific factors and macroeconomic factors [14]. Rajan and Dhal found that macroeconomic factors have significant impact on NPLs. They used a panel regression analysis for their study [44]. Statistical analysis by Waweruand Kalini on the commercial banks in Kenya also found that high macroeconomic condition is one of the factors of NPLs. Islam and Nishiyama present the empirical results on how bank specific, industry specific and macroeconomics specific factors affect the bank non-performing loan s in south Asian countries by using GMM estimator [25]. Waqas, Fatima, Khan and Arif M. show that both macroeconomic and bank specific variables are significantly related to NPLs [54]. Roy, Dey and Bhowmik show that two macro-economic variables GDP growth and inflation are negatively related to NPL in Bangladesh [44].

There is no literature which attempts to explore the causal relationship between GDP growth and NPL rate in Bangladesh using Toda-Yamamoto approach. Thus, this study aims to investigate the the causal relationship between GDP growth and NPL rate in Bangladesh using Toda-Yamamoto approach.

\section{Methodology}

\subsection{Data Collection}

GDP growth rate of Bangladesh and NPL data of all the 56 scheduled banks in Bangladesh is collected from secondary sources for the period from 2000 to 2017. NPL data is collected from Annual Reports of Bangladesh Bank of different years. GDP growth rate data is collected from World Bank group database.

\subsection{Data Analysis}

"STATA 15" statistical software package is used for both descriptive and quantitative analysis of the collected data. The present scenario of NPL in Bangladesh and the economic indicators are presented through the descriptive analysis. In quantitative analysis, Augmented Dickey-fuller Unit Root Test is done to check the stationarity. Toda-Yamamoto test is done to identify the causal relationship among the variables.

\subsection{Toda-Yamamoto Causality Test}

It is an augmented Granger causality test. This procedure uses a modified Wald test for restrictions on the parameters of the vector autoregressive VAR (p) model. The test has an asymptotic Chi-squared distribution with $\mathrm{p}$ degrees of freedom in the limit when a VAR $(p+d m a x)$ is estimated (where dmax is the maximal order of integration for the series in the system). The main merit of the Toda-Yamamoto procedure is that it can be used irrespective of whether the time series in the system are integrated of different orders or non-cointegrated or both [49].

The procedures are as below -

Step-1: Augmented Dickey-Fuller is done to determine the maximal order of integration (dmax)

Step-2: Determining the optimal lag length (p) of the VAR in levels using the information criteria

Step-3: Applying the modified Wald procedure to the VAR $(\mathrm{k})$, where $\mathrm{k}=\mathrm{p}+\mathrm{dmax}$, using the following $\operatorname{VAR}(\mathrm{k})$ models:

$$
\begin{gathered}
N P L_{t}=\alpha_{1}+\sum_{i=1}^{k} \beta_{1 i} N P L_{t-i}+\sum_{i=1}^{k} \gamma_{1 i} G P D G R_{t-i}+\epsilon_{1} \\
G D P G R_{t}=\alpha_{2}+\sum_{i=1}^{k} \beta_{2 i} N P L_{t-i}+\sum_{i=1}^{k} \gamma_{2 i} G P D G R_{t-i}+\epsilon_{2}
\end{gathered}
$$

In equation (1) if $\gamma_{11}=\gamma_{12}=\cdots=\gamma_{1 p} \neq 0$, in that case GDPGR has causal impact on NPL. Similarly, In equation (2) if $\beta_{21}=\beta_{22}=\cdots=\beta_{2 p} \neq 0$, then NPLR has causality on GDPGR.

\section{Discussion and Findings}

\subsection{Descriptive Statistics}

The mean, standard deviation, minimum and maximum value of the variables for the period from 2000 to 2017 is presented in Descriptive statistics. 
Table 1. Descriptive Statistics.

\begin{tabular}{lllll}
\hline Variable & Mean & Standard Deviation & Minimum & Maximum \\
\hline NPLR & 14.6 & 8.7 & 6.1 & 34.9 \\
GDPGR & 5.9 & 0.9 & 3.8 & 7.3 \\
\hline
\end{tabular}

Source: Compiled by the author based on collected data

Table 2. NPL and GDP growth trend in Bangladesh.

\begin{tabular}{lll}
\hline YEAR & NPLR (\%) & GDPGR (\%) \\
\hline 2000 & 34.9 & 5.29 \\
2001 & 31.5 & 5.08 \\
2002 & 28.0 & 3.83 \\
2003 & 22.1 & 4.74 \\
2004 & 17.6 & 5.24 \\
2005 & 13.6 & 6.54 \\
2006 & 13.2 & 6.67 \\
2007 & 13.2 & 7.06 \\
2008 & 10.8 & 6.01 \\
2009 & 9.2 & 5.05 \\
2010 & 7.3 & 5.57 \\
2011 & 6.1 & 6.46 \\
2012 & 10.0 & 6.52 \\
2013 & 8.9 & 6.01 \\
2014 & 9.7 & 6.06 \\
2015 & 8.8 & 6.55 \\
2016 & 9.2 & 7.11 \\
2017 & 9.3 & 7.28 \\
\hline
\end{tabular}

Sources: NPLR from various reports published by Bangladesh Bank and GDPGR from World Bank Database

\subsection{Augmented Dickey Fuller Unit Root Test Result}

Augmented Dickey Fuller Unit Root Test has been done to identify that weather all the variables are stationary or not. All the variables under this study must be stationary to perform regression analysis. The result of the test is as follows:
Table 3. Augmented Dickey Fuller Unit Root Test - 1.

\begin{tabular}{llll}
\hline Variable & T Statistic & Significance level & I (d) \\
\hline NPLR & -4.283 & $1 \%$ & I (0) \\
GDPGR & -3.262 & $5 \%$ & I (1) \\
\hline
\end{tabular}

Variable NPLR is found stationary at level $\mathrm{I}(0)$ at significance level of $1 \%$ and GDPGR found stationary at level I(1) at significance level 5\% Thus, the maximum order of integration $\mathrm{dmax}=1$.

\subsection{Optimal Lag Length Selection}

Table 4. Optimal Lag Length.

\begin{tabular}{ll}
\hline Lag & AIC \\
\hline 0 & 7.21152 \\
1 & 5.52305 \\
2 & $5.4621^{*}$ \\
3 & 5.63326 \\
4 & 5.89937 \\
\hline
\end{tabular}

Table 4 reports that, lag 2 is the optimum lag length as selected by AIC. Thus the optimum lag length i.e $\mathrm{p}=2$.

\subsection{Findings from Granger Causality Test}

Table 5 exhibits that there is unidirectional causal relationship exists between the variables i.e GPDGR granger causes NPLR as null hypothesis rejected at $1 \%$ level of significance and NPLR does not granger cause GPDGR.

Table 5. Granger Causality Test Results.

\begin{tabular}{lll}
\hline Null Hypothesis & P- value & Decision \\
\hline GDPGR does not Granger Cause NPLR & 0.002 & Null Hypothesis rejected \\
NPLR does not Granger Cause GDPGR & 0.684 & Null Hypothesis Cannot be rejected \\
\hline
\end{tabular}

Vardar $G$ also founds the same result i.e an unidirectional causal relationship between GDP and NPL using the data of Turkish banking sector ranging from 2007 to 2015 [20].

Sheefeni J examined the data of Namibian banking sector and also founds the unidirectional causal relationship between GDP and NPL [46]. These results are found consistent with the findings of the other similar research. The results revealed that all the macroeconomic determinants play a role in determining non-performing loans. This suggests that the macroeconomic environment is very critical for non-performing loans in the Bangladesh context.

\section{Conclusion and Recommendations}

Non-performing loans are considered as one of the most hazardous factors for any Banking industry. The banks having high level of NPLs requires to keep higher level of provision for loan loss that decreases the bank's revenue and reduces the funds for new lending. This study attempts to investigate the causal relationship between GDPGR and NPLR in in Bangladesh using secondary data. This study explores that there is a unidirectional causality from GDPGR to NPLR in Bangladesh. Thus, GDP growth rate is an important determinant of NPL in Bangladesh. The policy maker should consider the level of GDP growth while making policy regarding credit risk management, loan classification, single borrower exposure limit, money supply etc. The GDP growth rate also should be taken into consideration by the Banks while increasing their loan portfolio. 


\section{References}

[1] Achou, FT \& Tenguh, CN 2008, "Bank performance and credit risk management", MA Degree Project in Finance, Skovode Univercity.

[2] Anastasiou, D., Louri, H., and Tsionas, M. 2016, "Determinants of non-performing loans: Evidence for euro area countries", Finance Research Letters, Vol. 18, pp. 116-119.

[3] Anastasiou, D., Louri, H., and Tsionas, M., 2016, "Non-Performing Loans in the Euro Area: Are Core-Periphery Banking Markets Fragmented?", Bank of Greece Working Paper Series, Vol. No. 219.

[4] Aremu, M. A., Mejabi 2013, Determinants of banks profitability in developing economy: 4 (9) pp. 155-181.

[5] Ahmed, SZ 2006, "An investigation of the relationship between Non-performing Loans, Macroeconomic Factors, and Financial Factors in context of Private Commercial Banks in Bangladesh”, Independent University, Bangladesh.

[6] Baudino and Yun 2017, FSI Insights on policy implementation No 3, "Resolution of nonperforming loans - policy options".

[7] Bartel, J. and Huang, Y. 2000, "Dealing with the Bad Loans of the Chinese Banks", Columbia University Discussion Paper Series Discussion Paper No. 13.

[8] Bangladesh Bank 2012: Master Circular on Loan Classification and Provisioning, issued by Banking Regulation \& Policy Department, BRPD Circular No. 14 date: September 23, 2012.

[9] Basu, S 2003, "Why do Banks Fail?", International Review of Applied Economics, Vol. 17, pp. 231-248.

[10] BCBS 2017, "Prudential treatment of problem assets definitions of non-performing exposures and forbearance".

[11] Berger, NA and DeYoung, R 1997, "Problem Loans and Cost Efficiency in Commercial Banks", Journal of Banking and Finance, Vol. XV, No. 21, pp. 849-870.

[12] Booth, J. R. \& Booth, L. C. 2006, "Loan collateral decisions and corporate borrowing costs", Journal of Money, Credit and Banking, Vol. 38, pp. 67-90.

[13] Bloem, AM \& Freeman, R 2005, "The Treatment of Nonperforming Loans in Macroeconomic Statistics", IMF Working Paper WP/01/209, International Monetary Fund.

[14] Bercoff, Jose J., Julian di, Giovanni \& Franque Grimard. 2002. Argentinean Banks, Credit Growth and the Tequila Crisis: A Duration Analysis" (Unpublished)

[15] Campbell, A. 2007, "Bank insolvency and the problem of non-performing loans", Journal of Banking Regulation, Vol. 9 (1), pp. 25-45.

[16] Coco, G. 2000, "On the use of collateral”, Journal of Economic Surveys, Vol. 14, pp. 191-214.

[17] Espinoza, R., and Prasad A. 2010, "Nonperforming loans in the GCC banking system and their macroeconomic effects", IMF Working Paper, No. 10/224.

[18] Ekanayake \& Azeez 2015, "Determinants of Non-Performing Loans in Licensed Commercial Banks: Evidence from Sri Lanka". Asian Economic and Financial Review, 2015, 5 (6), pp 868-882.
[19] Fofack, H 2005, "Nonperforming loans in Sub-Saharan Africa: Causal Analysis and Macroeconomic implication" World Bank Policy Research Working Paper 3769, //econ.worldbank.org.

[20] Vardar, G. 2015, "Short Term and Long Term Linkage among Nonperforming Loan, Macroeconomic and Bank-specific Factors: An Empirical Analysis for Turkey", Ege Academic Review, Vol. 15 (3), pp. 313-325.

[21] $\mathrm{Hu}, \mathrm{J}, \mathrm{Li}, \mathrm{Y}$, and Chiu, Y 2004, "Ownership and nonperforming loans: Evidence from Taiwan's banks", The Developing Economics, Vol. 42, No. 3, PP. 405-420.

[22] Hou, Y 2006, "the non-performing loan problem: some bank level evidence", University of Birmingham Edgbaston, Birmingham.

[23] IMF (2015), 'Euro area policies, selected issues: policy options for tackling non- performing loans in the euro area', IMF country report, Vol. 15/205.

[24] Issa, AG 2009, “Analysis of non-performing loans in the Libyan state-owned commercial banks: perception analysis of the reasons and potential methods for treatment", PHD thesis, Durham University.

[25] Islam, S., Nishiyama, S. 2016. The determinants of non-performing loans: dynamic panel evidence from South Asian countries. TERG Discussion Papers 353, Graduate School of Economics and Management, Tohoku University.

[26] Justice Mustafa Kamal 2004, "Judicial Settlement and Mediation in Bangladesh", HRPB.

[27] Jovovic 2014, "Determinants of Non-Performing Loans: Econometric Evidence Based on 25 Countries. Master Thesis, City University London.

[28] Keeton W. \& C. S. Morris. 1987. Why Do Banks' Loan Losses Differ? Federal Reserve Bank of Kansas City, Economic Review, May, pp. 3-21.

[29] KPMG (2016), "European debt sales“, Loan portfolio advisory, Portfolio Solutions Group, KPMG International.

[30] Khan J, Khan I (2018) The Impact of Macroeconomic Variables on Stock Prices: A Case Study of Karachi Stock Exchange. Bus Eco J 9: 365.

[31] Laeven, L., Majnoni G. 2003, "Loan Loss Provisioning and Economic Slowdowns: Too Much, Too Late?" Journal of Financial Intermediation, Vol. 12, No 2, pp. 178-197.

[32] Lee, S. 2002, "Financial Restructuring in Korea and Japan: Resolution of Non-performing loans and reorganization of financial institutions", Journal of East Asian Studies, Vol. 2, pp. 143-185.

[33] Leeth, J. D. \& Scott, J. A. 1989, "The incidence of secured debt: Evidence from the Small Business Community", Journal of Financial and Quantitative Analysis, Vol. 24, pp. 379-394.

[34] Lehmann, A. 2017, "Carving out legacy assets: a successful tool for bank restructuring?", European Parliament's Committee on Economic and Monetary Affairs - Policy Contribution Issue, No. 9.

[35] Lis, S. F. de, J. M. Pages, and Saurina, J., (2000), Credit growth, problem loans and credit risk provisioning in spain. Banco de España - Servicio de Estudios, Documento de Trabajo no 0018 . 
[36] Louzis, D., Vouldis A., Metaxas, V. 2010, 'Macroeconomic and bank-specific determinants of non-performing loans in Greece: A comparative study of mortgage, business and consumer loan portfolios', Journal of Banking and Finance, Vol. 36 (4), pp. 1012-1027.

[37] Masood, O., Bellalah, M., and Mansour, W. 2010, "Non-Performing Loans and Credit Managers' Role: A Comparative Approach from Pakistan and Turkey", International Journal of Business, Vol. 15 (3), pp. 347-362.

[38] Matoušek R. and Bruno S. 2005, "Management of Non-Performing Loans in Eastern Europe", Journal of East-West Business, Vol. 11 (1), pp. 141-166.

[39] Makri, Tsagkanos \& Bellas 2014, "Determinants of Non-Performing Loans: The case of Eurozone". Panoeconomicus, 61 (2), pp 193-206

[40] New Zealand's Ombudsmen Act 1975.

[41] Nkusu, W 2011, "Nonperforming Loans and Macrofinancial Vulnerabilities in Advanced Economies" International Monetary Fund, Vol. 11, No. 161.

[42] Pesaran, M. H., and Y. Shin (1998). An autoregressive distributed-lag modelling approach to cointegration analysis. In Econometrics and Economic Theory in the 20th Century. The Ragnar Frisch Centennial Symposium, ed. S. Strom, chap. 11, 371-413. Cambridge: Cambridge University Press.

[43] PWC 2017, "Non-performing loans - Leveraging the right strategy to optimise your company's balance sheet".

[44] Rajan, Rajiv \&Sarat C. Dhal. 2003. Non-performing Loans and Terms of Credit of Public Sector Banks in India: An Empirical Assessment. Occasional Papers, 24: 3, pp. 81-121, Reserve Bank of India.

[45] Roy, Dey and Bhowmik 2017, Non-performing loans in private commercial banks of Bangladesh: Macro-economic determinants and impacts, The Jahangirnagar Journal of Business Studies. 4 (1): 47-57.

[46] Sheefeni, J. 2015, "The Impact of Macroeconomic Determinants on Nonperforming Loans in Namibia".
International Review of Research in Emerging Markets and the Global Economy, Vol. 1 (4), pp 612-632.

[47] Sinkey, Joseph. Fowler. \& Mary B. Greenwalt 1991, Loan-Loss Experience and Risk-Taking Behavior at Large Commercial Banks, Journal of Financial Services Research, 5: 43-59.

[48] Salas, Vincente \& Jesus Saurina 2002. Credit Risk in Two Institutional Regimes: Spanish Commercial and Savings Banks. Journal of Financial Services Research, 22: 3, pp. 203-224.

[49] Toda, H. Y., Yamamoto, T. (1995) Statistical inference in vector auto-regressions with partially integrated processes. Journal of Econometrics 66: 225-250.

[50] Turner, P. and Hawkins, J. (1999), 'Bank restructuring in practice: an overview', Policy Papers No. 6, Bank for International Settlements.

[51] USAID: Alternative dispute resolution practitioners guide, CMG's Advisory Group of ADR and conflict management experts includes Professors Frank Sander and David Smith of Harvard Law School; Robert Ricigliano, CMG Executive Director; Diana Chigas, CMG Regional Director; and Antonia Handler Chayes, CMG Senior Advisor.

[52] Woo, D. (2000), "Two Approaches to Resolving Nonperforming Assets During Financial Crises', ' International Monetary Fund Vol No. 33.

[53] Waweru, N. M. \& Kalani, V. M. 2009, Commercial banking crises in Kenya: causes and remedies, African Journal of Accounting, Economic Economics, Finance and banking research, 4 (4): 12-32.

[54] Waqas, Fatima, Khan and Arif M. 2017, Determinants of Non-performing Loans: A Comparative Study of Pakistan, India, and Bangladesh, International Journal of Finance \& Banking Studies, 6 (1): 51-68.

[55] www.bangladesh-bank.org/ November, 2018.

[56] Xu, M. (2005), "Resolution of Non-Performing Loans in China", the Leonard N. Stern School of Business Glucksman Institute for Research in Securities Markets. 